\title{
Anti-tumoral effects of a trypsin inhibitor derived from buckwheat in vitro and in vivo
}

\author{
CHONG-ZHI BAI ${ }^{1,2}$, MA-LI FENG ${ }^{2}$, XU-LIANG HAO ${ }^{2}$, ZHI-JUAN ZHAO $^{1}$, \\ YU-YING $\mathrm{LI}^{1}$ and ZHUAN-HUA WANG ${ }^{1}$ \\ ${ }^{1}$ Key Laboratory for Chemical Biology and Molecular Engineering of the Ministry of Education, \\ Institute of Biotechnology, Shanxi University, Taiyuan, Shanxi 030006; ${ }^{2}$ Chinese Medicine Hospital of Shanxi Province, \\ Taiyuan, Shanxi 030012, P.R. China
}

Received June 23, 2014; Accepted March 23, 2015

DOI: $10.3892 / \mathrm{mmr} .2015 .3649$

\begin{abstract}
Native buckwheat, a common component of food products and medicine, has been observed to inhibit cancer cell proliferation in vitro. The aim of the present study was to evaluate the in vitro and in vivo anti-tumoral effects of recombinant buckwheat trypsin inhibitor (rBTI) on hepatic cancer cells and the mechanism of apoptosis involved. Apoptosis in the H22 cell line induced by rBTI was identified using MTT assays, DNA electrophoresis, flow cytometry, morphological observation of the nuclei, measurement of cytochrome $\mathrm{C}$ and assessment of caspase activation. It was identified that rBTI decreases cell viability by inducing apoptosis, as evidenced by the formation of apoptotic bodies and DNA fragmentation. rBTI-induced apoptosis occurred in association with mitochondrial dysfunction, leading to the release of cytochrome $\mathrm{C}$ from the mitochondria to the cytosol, as well as the activation of caspase-3, -8 and -9 . In conclusion, the results of the present study suggested that rBTI specifically inhibited the growth of the $\mathrm{H} 22$ hepatic carcinoma cell line in vitro and in vivo in a concentration-dependent and time-dependent manner, while there were minimal effects on the 7702 normal liver cell line. In addition, rBTI-induced apoptosis in H22 cells was, at least in part, mediated by a mitochondrial pathway via caspase-9.
\end{abstract}

\section{Introduction}

Buckwheat, an important functional food planted at high latitudes and in colder climates, is a common dietary component in East Asian countries (1). It is high in protein, contains a number of amino acids and is regarded as a popular food

Correspondence to: Dr Zhuan-Hua Wang, Key Laboratory for Chemical Biology and Molecular Engineering of the Ministry of Education, Institute of Biotechnology, Shanxi University, $92 \mathrm{Wu}$ cheng Road, Taiyuan, Shanxi 030006, P.R. China

E-mail: zhwang@sxu.edu.cn

Key words: common buckwheat, trypsin inhibitor, hepatocellular carcinoma, apoptosis, anti-tumor globally, particularly in Asia. Buckwheat protein has high biological value due to its well-balanced amino acid composition and its high level of lysine $(2,3)$. Protease inhibitors are widely distributed in nature and are found in numerous animals, plants and microorganisms. They are important in maintaining the balance of proteolytic enzymes in vivo. In addition, they regulate endogenous proteases during germination and protect plants against insects and microorganisms (4-6). Of note, the inhibitors have been found to exhibit anti-carcinogenic activities and act as cancer-preventive and anti-inflammatory agents (7-9). Protease inhibitors are capable of inducing the apoptosis of cancer cells in vitro and they have drawn attention as potential anti-cancer agents (10). The Bowman-Birk inhibitor family of proteins attained from soybeans are associated with anti-inflammatory and anti-carcinogenic activities (11), and are potentially relevant anti-tumor agents, particularly with regard to colon cancer (12).

Numerous lines of evidence have suggested that protease inhibitors may induce apoptosis in various tumor cell lines; however, the underlying mechanisms of their anti-tumor activity remain to be elucidated. Induction of tumor cell apoptosis is a common mechanism of action of cancer therapeutics $(13,14)$. Caspase-3 is one of the key initiators of apoptosis via the mitochondrial pathway and an essential factor for the activation of the caspase cascade (15-17). Recent studies have revealed that the activation of caspase-9 also induced the activation of the caspase cascade, triggering apoptotic events and inducing cell apoptosis $(15,18,19)$. In addition, another pathway associated with apoptosis is the extrinsic pathway, which is associated with death receptors, including Fas. Adaptor molecules are recruited to the receptors following Fas ligand binding to the Fas death receptor, initiating the program of apoptosis $(16,20,21)$.

Previous studies by our group revealed that a trypsin inhibitor from buckwheat was able to markedly inhibit the proliferation of the IM-9 and K562 cell lines in vitro $(22,23)$. In order to elucidate whether the recombinant buckwheat trypsin inhibitor (rBTI) has the same effect in vivo and which apoptotic pathway is activated following rBTI treatment, the effect of rBTI treatment on the proliferation of $\mathrm{H} 22$ hepatic carcinoma cells was investigated in vitro and in vivo. 


\section{Materials and methods}

Materials. The H22 hepatic carcinoma cell line and the 7702 normal liver cell line were obtained from the Third Hospital of Shanxi Medical University (Taiyuan, China) and China Radiation Defense and Preservation Institute (Taiyuan, China). For all experiments, $4-6$ week-old female BALB/c mice (50 mice; 18-22 g) purchased from the Institute of Laboratory Animal Science, Chinese Academy of Medical Sciences (Beijing, China) were used. All mice were group-housed in plastic cages with stainless-steel grid tops in a room under a 12-h light/dark cycle and fed with distilled water and food. The general health status of the animals was monitored daily. An abdominal injection of the $\mathrm{H} 22$ cells $\left(0.2 \mathrm{ml} 10^{6}\right.$ cells $/ \mathrm{ml}$ with $0.1 \mathrm{ml}$ normal saline) was administered to the BALB/c mice. The cell culture medium was composed of RPMI-1640 (Gibco-BRL, Invitrogen Life Technologies, Carlsbad, CA, USA) supplemented with $10 \%$ fetal calf serum (Institute of Hematology, Hangzhou, China), $100 \mathrm{U} / \mathrm{ml}$ streptomycin and penicillin solution $(100 \mathrm{U} / \mathrm{ml})$ purchased from the Cell Culture Center of the Institute of Basic Medical Sciences, Chinese Academy of Medical Sciences. The cells were incubated at $37^{\circ} \mathrm{C}$ under humidified conditions with $5 \% \mathrm{CO}_{2}$. MTT was purchased from Sigma-Aldrich (St. Louis, MO, USA). An Annexin V-fluorescein isothiocyanate Apoptosis Detection kit was obtained from BD Pharmingen (San Diego, CA, USA). An apoptosis DNA Ladder Detection kit was purchased from Nanjing KeyGen Biotech Co., Ltd. (Nanjing, China). A Cytochrome C Detection kit and Caspase-3, - 8 and-9 Colorimetric Assay kits were obtained from BioVision (Mountain View, CA, USA). The rBTI was prepared in our laboratory by cloning, expression and one-step affinity purification as described previously $(22,23)$. All other chemicals used were of analytical grade. The current study was approved by the Ethics Committee of Shanxi University (Taiyuan, China).

Cell viability assay. The cell viability was assessed using an MTT assay. The MTT assay is a colorimetric assay, which measures the percentage of surviving cells. The H22 and 7702 cell lines were separately transferred to quadruplicate wells of 96-well microtiter plates at a density of $5 \times 10^{3}$ cells/well. The cells were treated with rBTI at concentrations of $(6.25,12.5$, 25 and $50 \mu \mathrm{g} / \mathrm{ml}$ for 12,20 and $24 \mathrm{~h}$, each group investigated in triplicate. A total of $20 \mu \mathrm{l}$ MTT $(5.0 \mathrm{mg} / \mathrm{ml})$ was added and the cells were incubated for $4 \mathrm{~h}$. Following this, $80 \mu \mathrm{l}$ dimethyl sulfoxide was added. The color intensity was measured using a microtiter plate reader (Model 550; Bio-Rad Laboratories, Inc., Hercules, CA, USA) at $570 \mathrm{~nm}$. The absorbance of the untreated cells was considered to be $100 \%$. The $50 \%$ inhibitory concentration was the concentration at which a $50 \%$ decrease in the optical density of the drug-treated cells was induced, with respect to untreated cells.

Morphological observation of nuclei. Following treatment with $\mathrm{rBTI}(50 \mu \mathrm{g} / \mathrm{ml})$ for $24 \mathrm{~h}$, the $\mathrm{H} 22$ cells were washed with phosphate-buffered saline (PBS; pH 6.7; Sigma-Aldrich) and centrifuged $(2,000 \mathrm{xg})$, then incubated with $4 \%$ paraformaldhyde (Sigma-Aldrich) for $10 \mathrm{~min}$. Subsequently, the cells were collected via centrifugation $(2,000 \mathrm{xg})$. The cells were stained with $0.1 \mu \mathrm{g} / \mathrm{ml}$ DAPI (Sigma-Aldrich) for $5 \mathrm{~min}$. Fluorescence microscopy was then used to observe the nuclear morphology.
DNA fragmentation analysis. Following treatment with various concentrations of $\operatorname{rBTI}(12.5,25$ or $50 \mu \mathrm{g} / \mathrm{ml})$, a total of $1 \times 10^{6}$ $\mathrm{H} 22$ cells were collected. The DNA of the H22 cells treated with rBTI was extracted according to a procedure described in a previous study by our group (23). The extracted DNA was analyzed on a $1.0 \%$ agarose gel (Sigma-Aldrich) with the GeneGenius Bio Imaging system (SynGene, Frederick, MD, USA) and observed under ultraviolet light with an FV1000 fluorescent microscope (Olympus, Tokyo, Japan).

Flow cytometric analysis of cell apoptosis. Following treatment with $\mathrm{rBTI}(12.5,25$ or $50 \mu \mathrm{g} / \mathrm{ml})$ for $24 \mathrm{~h}$, the cells were adjusted to $1 \times 10^{6}$ in $50 \mathrm{mM}$ PBS at $\mathrm{pH} 7.6$ and centrifuged at $2,000 \mathrm{xg}$. A total of $100 \mu \mathrm{l}$ binding buffer was then added to re-suspend the cells. Annexin V and propidium iodide were added to the cell suspension followed by a 20-min incubation, and the cells were then analyzed using flow cytometry using an FC500 Flow Cytometer (BD Biosciences, Franklin Lakes NJ, USA) (9).

Measurement of cytochrome $\mathrm{C}$ in mitochondria and cytoplasm. Extraction of cytochrome C. Following treatment with rBTI $(25$ or $50 \mu \mathrm{g} / \mathrm{ml})$ for $24 \mathrm{~h}, 1 \times 10^{6} \mathrm{H} 22$ cells were washed with cold PBS. The cells were then centrifuged at $600 \mathrm{xg}$ for $5 \mathrm{~min}$ at $4^{\circ} \mathrm{C}$. The supernatant was then removed and the cells were re-suspended in $1.0 \mathrm{ml}$ cytosol extraction buffer. The samples were incubated on ice for $10 \mathrm{~min}$. The homogenate was then transferred to a $1.5-\mathrm{ml}$ microcentrifuge tube and centrifuged at $700 \mathrm{xg}$ for $10 \mathrm{~min}$ at $4^{\circ} \mathrm{C}$. The supernatant was then collected into a fresh $1.5-\mathrm{ml}$ tube and centrifuged at $10,000 \mathrm{xg}$ for $30 \mathrm{~min}$ at $4^{\circ} \mathrm{C}$. The supernatant was then collected as the cytosolic fraction. The pellet was re-suspended in $0.1 \mathrm{ml}$ mitochondrial extraction buffer mix with protease inhibitors, vortexed for $10 \mathrm{sec}$ and saved as the mitochondrial fraction. After extracting cytochrome $\mathrm{C}$ from the mitochondria and cytoplasm, cytochrome $\mathrm{C}$ was electrophoresed using $15 \%$ SDS-PAGE.

Western blot analysis. The protein concentration was determined using a BCA Protein Assay kit (Lanbao Biotechnology, Shanghai, China) according to according to the manufacturer's protocol. The protein was electrophoresed using $15 \%$ SDS-PAGE (as described above) and transferred onto nitrocellulose membranes (Beyotime Institute of Biotechnology, Shanghai, China). Following blocking, the membranes were incubated for $4 \mathrm{~h}$ at $37^{\circ} \mathrm{C}$ with the primary antibody, which was goat anti-mouse monoclonal anti-cytochrome $\mathrm{C}$ (1:400; IM 94638; Beyotime Institute of Biotechnology), and the secondary antibody (1:5,000; 572909; Beyotime Institute of Biotechnology), which was goat anti-rat alkaline phosphatase-conjugated immunoglobulin E. The blots were visualized using enhanced chemiluminescence detection reagents (Beyotime Institute of Biotechnology) according to the manufacturer's instructions. The SynGene GeneTools analysis software-version 3.02.00 (SynGene, Frederick, MD, USA) was used to analyze the images and perform calculations.

Caspase colorimetric activation assessment. The cells, which were treated with $50 \mu \mathrm{g} / \mathrm{ml} \mathrm{rBTI}$ for $24 \mathrm{~h}$, were collected and 


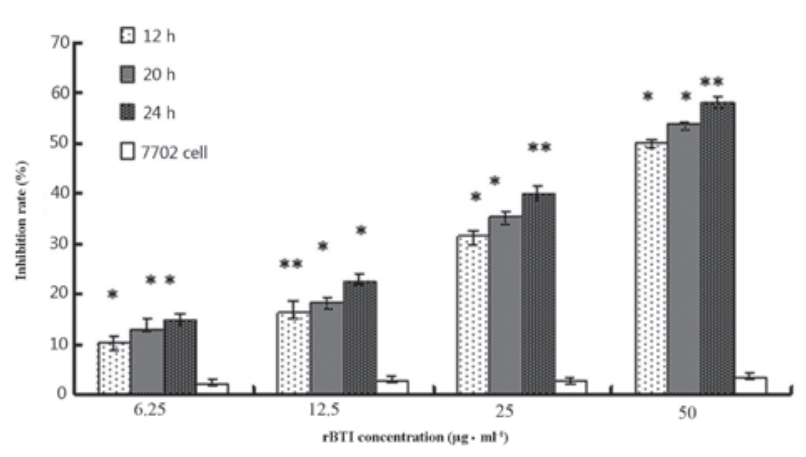

Figure 1. Effects of rBTI treatment on the $\mathrm{H} 22$ and 7702 cell lines. Cells were incubated with various concentrations of rBTI. ${ }^{*} \mathrm{P}<0.05,{ }^{* *} \mathrm{P}<0.01$ compared with 7702 cells. Results are expressed as the mean \pm standard error. rBTI, recombinant buckwheat trypsin inhibitor.

prepared via incubation with extraction buffer for $30 \mathrm{~min}$ and centrifugation at $15,000 \mathrm{xg}$ for $20 \mathrm{~min}$. Subsequently, the supernatant was collected and the protein concentration was assessed. The protein concentration was determined using a bicinchoninic acid protein assay kit (Beyotime Institute of Biotechnology). The extracts were incubated in a 96-well microtitre plate with three types $p$-nitroanilide (pNA): Asp-Glu-Val-Asp-pNA for caspase-3, Ile-Glu-Thr-Asp-pNA for caspase-8 and Leu-Glu-His-Asp-pNA for caspase-9, respectively, for $2 \mathrm{~h}$ at $37^{\circ} \mathrm{C}$ (BioVision). The absorbance was then measured at $405 \mathrm{~nm}$.

Animal experiment. The anti-tumoral activity of rBTI against ascites development was evaluated in mice. Following the development of ascites, the peritoneal cavity was washed with $2 \mathrm{ml}$ PBS following treatment with $2.5 \mathrm{mg} / 100 \mathrm{~g}$ pentobarbital (Westang Biotechnology, Shanghai, China). The mice were assigned randomly into five groups: The rBTI treatment groups (four groups) and the control group ( $\mathrm{n}=10$ per group). The drug $(0.125,0.25,0.50$ or $1.0 \mathrm{mg} / \mathrm{kg} ; 0.2 \mathrm{ml} \mathrm{rBTI})$ was administered via abdominal injection daily for eight days. The ascites volume was calculated using a burette and the cumulative ascites volume was calculated by adding these values. The total number of viable $\mathrm{H} 22$ cells present in the ascites fluid (peritoneal wash) was counted using a hemocytometer.

Statistical analysis. SPSS 12.0 for Windows (SPSS, Inc., Chicago, IL, USA) was used for statistical analysis. All values are expressed as the mean \pm standard error. Comparisons within groups were performed using a one-way analysis of variance and differences between groups were determined using Scheffé's method. $\mathrm{P}<0.05$ was considered to indicate a statistically significant difference.

\section{Results}

rBTI inhibits $\mathrm{H} 22$ cell proliferation in a dose- and time-dependent manner. The cell growth inhibitory activity of rBTI was assessed using a colorimetric MTT assay, as shown in Fig. 1. The growth inhibition rate of rBTI was 17.8, 27.3, 43.6 and $62.7 \%$ at concentrations of $6.25,12.5,25$ or $50 \mu \mathrm{g} / \mathrm{ml}$, respectively. The inhibitory effect of $\mathrm{rBTI}$ on the proliferation of $\mathrm{H} 22$ cells markedly increased as the concentration of rBTI
A

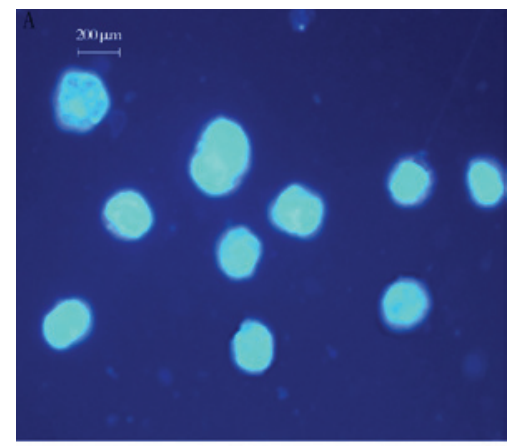

B

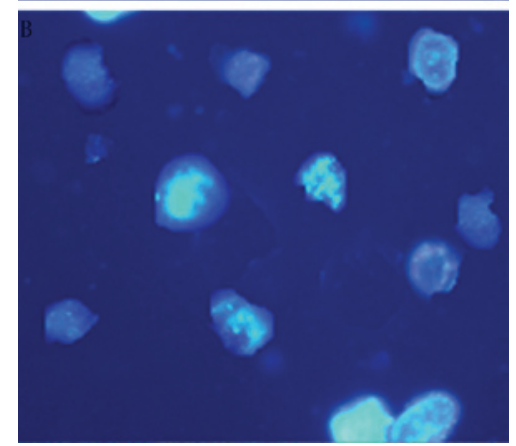

Figure 2. Representative images of normal and apoptotic H22 cells stained with DAPI following incubation without or with $50 \mu \mathrm{g} / \mathrm{ml}$ recombinant buckwheat trypsin inhibitor for $24 \mathrm{~h}$. (A) Control; (B) treated group.

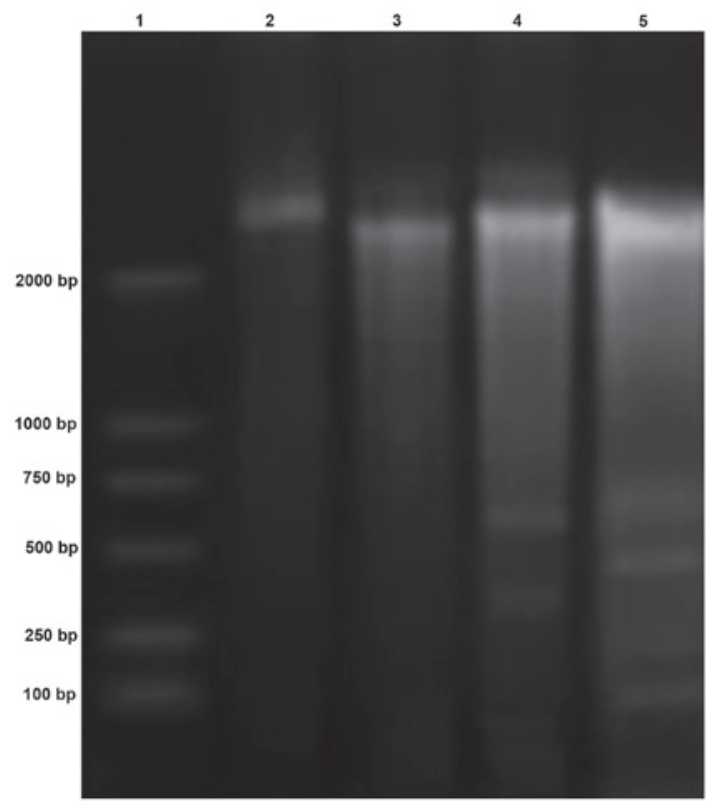

Figure 3. Internucleosomal DNA fragmentation in $\mathrm{H} 22$ cells treated with or without rBTI. Lanes 3, 4 and 5: DNA extracts treated with 12.5, 25 and $50 \mu \mathrm{g} / \mathrm{ml} \mathrm{rBTI}$, respectively. Lane 2: DNA extracts without treatment. rBTI, recombinant buckwheat trypsin inhibitor.

increased. Similarly, the inhibition rate was enhanced with increasing incubation time with the drug. The inhibitory effect of rBTI on the proliferation of $\mathrm{H} 22$ cells occurred in a dose-and time-dependent manner; however, there were minimal effects on the 7702 normal liver cell line.

Nuclear morphological observation. The apoptotic induction effect of rBTI on $\mathrm{H} 22$ cells was also investigated. As 

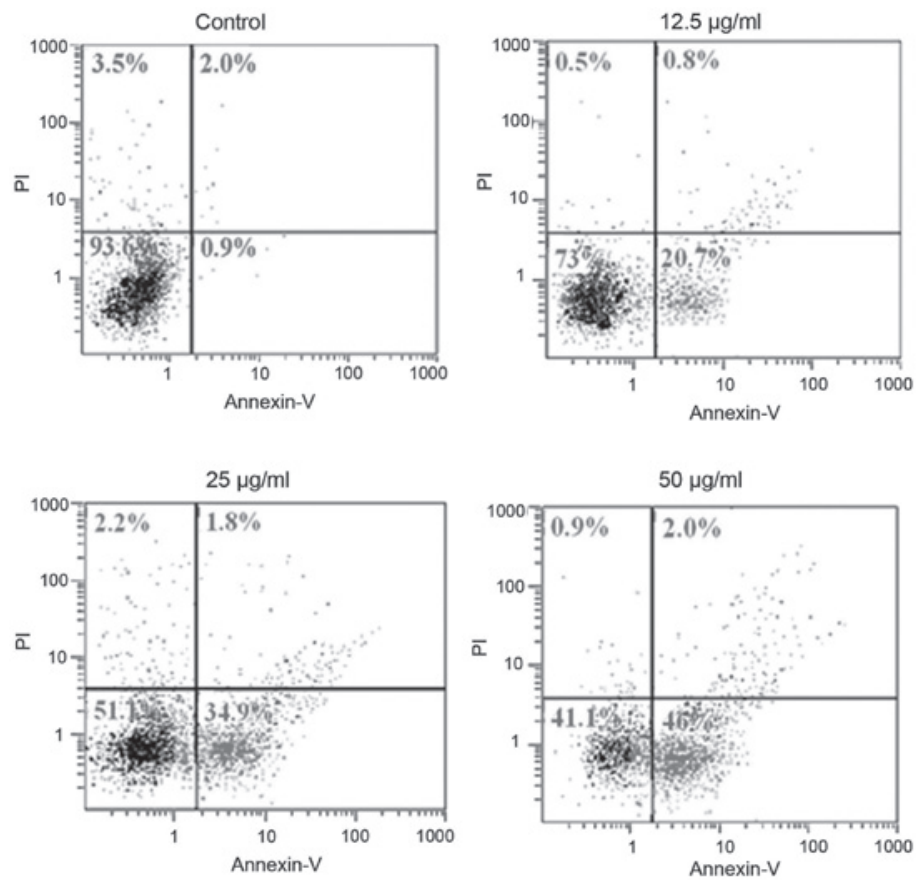

Figure 4. Flow cytometric analysis of apoptotic $\mathrm{H} 22$ cells induced by rBTI in a concentration-dependent manner. Cells were incubated with various concentrations of rBTI. rBTI, recombinant buckwheat trypsin inhibitor; PI, propidium iodide.

shown in Fig. 2, following $24 \mathrm{~h}$ of $50 \mu \mathrm{g} / \mathrm{ml} \mathrm{rBTI}$ treatment, there were significant changes to the cell morphology of H22 cells compared with that of the control cells. The typical characteristics of apoptosis, including membrane disintegration and apoptotic body formation, were also observed (Fig. 2B).

DNA electrophoresis band analysis. The results of the band analysis following DNA electrophoresis revealed that 200-base pair fragments were present following treatment with $50 \mu \mathrm{g} / \mathrm{ml}$ rBTI (Fig. 3). The bands of the DNA electrophoresis presented regularly, similar to a ladder. The band pattern exhibited typical features of apototic cells.

Flow cytometric analysis. Cell apoptosis in the H22 cell line was determined by flow cytometry with or without treatment with rBTI at various concentrations $(12.5,25$ or $50 \mu \mathrm{g} / \mathrm{ml})$ for $24 \mathrm{~h}$ (Fig. 4). The results revealed that the ratio of apoptotic cells increased with the increase in rBTI concentration. Significant differences were observed among each treatment group and the control.

Western blot analysis. Cytochrome $\mathrm{C}$ is important in cell apoptosis. It is located in the inter-membrane space between the two membranes. Cytochrome $\mathrm{C}$ is released from the mitochondria to the cytosol when the cell undergoes apoptosis. Fig. 5 demonstrates that cytochrome $\mathrm{C}$ was released from the mitochondria into the cytoplasm following treatment with $\mathrm{rBTI}$ for $24 \mathrm{~h}$ and following an increase in the concentration of rBTI from 25 to $50 \mu \mathrm{g} / \mathrm{ml}$. The quantities of cytochrome $\mathrm{C}$ in the cytosol were 54.1 and $74.6 \%$ of total cytochrome $\mathrm{C}$, respectively.

Caspase colorimetric activation assessment. As shown in Fig. 6, rBTI-induced apoptosis of $\mathrm{H} 22$ cells was predominantly

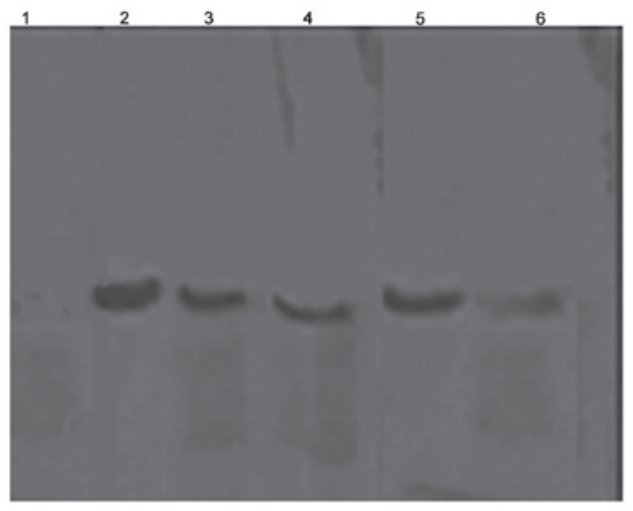

Figure 5. Western blot analysis of cytochrome C. Lanes 1, 3 and 5: Cytochrome $\mathrm{C}$ in the cytosol following 0,25 and $50 \mu \mathrm{g} / \mathrm{ml}$ recombinant buckwheat trypsin inhibitor treatment; lanes 2, 4 and 6: Cytochrome $\mathrm{C}$ in the mitochondria following 0,25 and $50 \mu \mathrm{g} / \mathrm{ml}$ treatment.

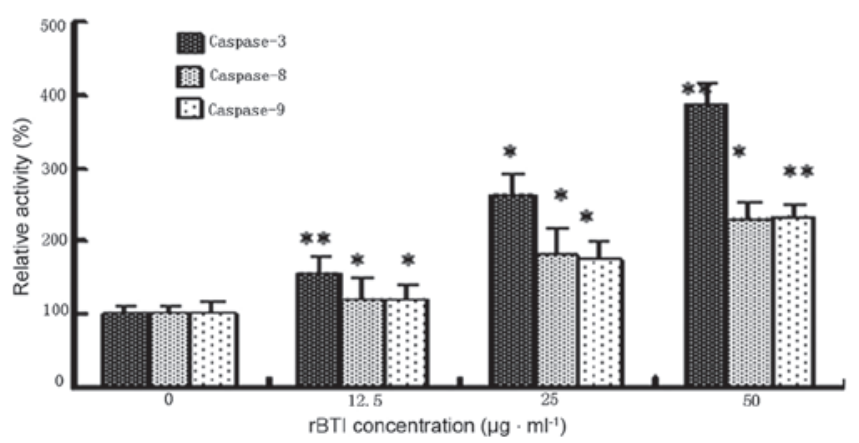

Figure 6. Relative activity of caspases by rBTI in H22 cells. Cell lysates from cells treated with rBTI for $24 \mathrm{~h}$ were assayed for in vitro caspase-3, -8 and -9 activity using Asp-Glu-Val-Asp-pNA, Ile-Glu-Thr-Asp-pNA and Leu-Glu-His-Asp-pNA, respectively, as substrates. Values are expressed as the mean \pm standard error of three independent experiments. ${ }^{*} \mathrm{P}<0.05$ ${ }^{* *} \mathrm{P}<0.01$, compared with untreated cells. rBTI, recombinant buckwheat trypsin inhibitor; PNA, $p$-nitroanilide. 

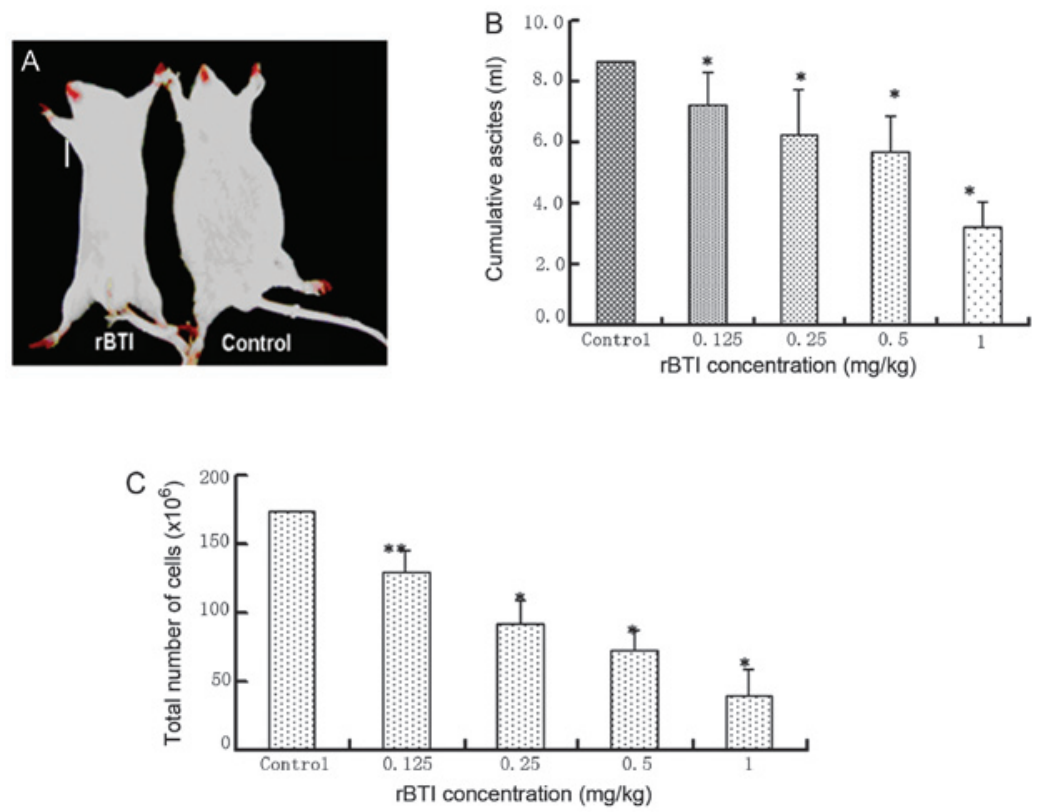

Figure 7. Effect of rBTI on ascites and cancer cell development. Mice inoculated with $\mathrm{H} 22$ cells developed ascites and were then randomly assigned to either the control or $\mathrm{rBTI}$ treatment group ( $\mathrm{n}=10$ per group). (A) All mice in the control group developed overt ascites; however, no macroscopic signs of ascites formation was observed in the $1 \mathrm{mg} / \mathrm{kg}$ rBTI-treated mice. (B) The volume of ascites present was recorded. The volume of ascites collected in each animal from the initiation of the treatment was tallied up to provide the cumulative ascites volume. (C) Total number of viable $\mathrm{H} 22$ cells present in the ascites fluid (peritoneal wash) was counted using a hemocytometer. ${ }^{*} \mathrm{P}<0.05,{ }^{* *} \mathrm{P}<0.01$ compared with untreated cells. Results are expressed as the mean \pm standard error of ten experiments. rBTI, recombinant buckwheat trypsin inhibitor.

associated with the activities of caspase- 3 in a concentration-dependent manner. In addition, caspase- 8 and caspase- 9 were slightly activated by rBTI. The results supported the hypothesis that rBTI predominantly induced apoptosis in the H22 cell line via the mitochondrial-mediated intrinsic apoptotic pathway involving caspase-3 and caspase-9.

Inhibition of ascites production in mice following treatment with rBTI. With the development of ascites generation, the abdominal content increased and mice $(7$ mice with no treatment, 4 mice treated with $0.125 \mathrm{mg} / \mathrm{kg}, 4$ mice treated with $0.25 \mathrm{mg} / \mathrm{kg}, 3$ mice treated with $0.5 \mathrm{mg} / \mathrm{kg}$ and 1 mouse treated with $1 \mathrm{mg} / \mathrm{kg}$ ) died throughout the course of the treatment (8 days). By contrast, mice treated with rBTI at various doses $(0.125,0.25,0.5$ and $1 \mathrm{mg} / \mathrm{kg})$ exhibited a reduction in visible ascites during the entire treatment period of 8 days, particularly those treated with rBTI at the highest concentration of $1 \mathrm{mg} / \mathrm{kg}$ (Fig. 7A). The cumulative volume of ascites was evaluated (Fig. 7B). The results revealed that ascites production was significantly suppressed following treatment with rBTI. Similarly, rBTI treatment led to a significant reduction in the quantity of intraperitoneal tumor cells (Fig. 7C).

\section{Discussion}

A preliminary study by our group revealed the efficient in vitro anti-tumoral effects of rBTI in K562 cells (23). In the present study, the potent anti-tumoral activity of rBTI was demonstrated in vitro and in vivo. The cell proliferation inhibition rates of rBTI were 17.8, 27.3, 43.6 and $62.7 \%$ at concentrations of $6.25,12.5,25$ or $50 \mu \mathrm{g} / \mathrm{ml}$, respectively. The inhibitory effect of rBTI on the proliferation of $\mathrm{H} 22$ cells occurred in a dose-dependent and time-dependent manner.
rBTI treatment induced caspase activation and also resulted in the translocation of cytochrome $\mathrm{C}$ from the mitochondria to the cytosol, as well as the cleavage of DNA, but no effect on the proliferation of normal liver cells was observed. This anti-tumoral activity was partly consistent with the reported biological effects of other inhibitors extracted from buckwheat seeds, including BWI-1 and BWI-2a, which were able to inhibit T-acute lymphoblastic leukemia cell growth in vitro (24). The caspase family, which is comprised of aspartate-specific cysteine proteases, is critical in the regulation of apoptosis. The key biochemical pathways of caspase activation are well known (25). Caspase signaling is initiated and propagated by proteolytic autocatalysis and the cleavage of downstream caspases and substrates, including poly adenosine diphosphate ribose polymerase and phospholipase $C-\gamma 1$ (26). In particular, caspase- 3 is one of the key executioners of apoptosis, as it is either partially or completely responsible for the proteolytic cleavage of a number of key proteins (27). The vast majority of cell death signals engage the mitochondrial pathway, where the cysteine protease, caspase-9, is recruited and activated (28). Activation of caspase- 9 is mediated by the formation of a macromolecular complex, termed the apoptosome, with the release of cytochrome $C$ from mitochondria (29). In the present study, it was first demonstrated that rBTI increases the release of cytochrome $\mathrm{C}$ from the mitochondria. The release of cytochrome $\mathrm{C}$ suggested that rBTI induced apoptosis through a mitochondrial pathway (Fig. 5), which is consistent with previous studies (18). In addition, caspase-3, -8 and -9 were activated, which are associated with the mitochondrial intrinsic apoptotic pathway. However, the underlying mechanisms of the induction of mitochondrial dysfunction following treatment with $\mathrm{rBTI}$ remain to be elucidated. rBTI may inhibit the synthesis of proteins, which maintain the mitochondrial 
membrane permeability as a protease inhibitor (30). In addition, it was identified that trypsin certain types of transmembrane protein have a high homology at the DNA level; therefore, rBTI possibly combines with the transmembrane protein and enters the cell, where it induces mitochondrial dysfunction.

The results of the present study also confirmed that $\mathrm{rBTI}$ is able to significantly suppress the ascites production in mice. The accumulation of malignant ascites is an important cause of cancer-associated morbidity and mortality in patients with peritoneal metastases (31). In the present study, it was revealed that rBTI was able to significantly suppress ascites formation in $\mathrm{H} 22$ tumor-bearing mice. The results clearly demonstrated an effect on the inhibition of proliferation in vitro and in vivo of rBTI. However, the mechanisms associated with tumor growth inhibition require further investigation.

In conclusion, $\mathrm{rBTI}$, a novel trypsin inhibitor, was shown to exhibit anti-tumoral activity in vitro and in vivo. rBTI exerted its effects in a dose- and time-dependent manner, while it only had minimal effects on the normal liver cell line 7702 . rBTI induced apoptosis by promoting mitochondrial dysfunction, thereby leading to caspase activation. The present study revealed a novel function of $\mathrm{rBTI}$ and supported its potential application in treating malignant ascites. The development of a trypsin inhibitor as an anti-tumoral agent requires further investigation.

\section{Acknowledgements}

The present study was supported by grants from the Natural Science Foundation of China (grant nos. 31171659 and 81173574) and Shanxi Provincial Experimental Animal Special Funds (grant no. 2011K04). The authors gratefully acknowledge the kind discussions and cooperation of the Central Laboratory of Chinese Medicine Hospital of Shanxi Province. The authors would also like to thank all the staff of the Institute of Biotechnology (Taiyuan, China) for their helpful technical assistance.

\section{References}

1. Li CH, Kobayasshi K, Yoshida Y and Ohsawa R: Genetic analyses of agronomic traits in Tartary buckwheat (Fagopyrum tataricum (L.) Gaertn.). Breed Sci 62: 303-309, 2012.

2. Pomeranz Y and Robbins GS: Amino acid composition of buckwheat protein. J Agric Food Chem 20: 270-274, 1972.

3. Ikeda $\mathrm{K}$ and Kishida M: Digestibility of proteins in buckwheat seed. Fagopyrum 13: 21-24, 1993.

4. Zhang Z, Li YY, Shi XR, et al: Gene cloning and sequencing of common buckwheat trypsin inhibitor. Acta Botanica Boreali-Occidentalia Sinica 25: 46-51, 2005.

5. Htay HH, Tsubouchi R, Haneda M, Murakami K and Yoshino M: Induction of apoptosis of HL60 cells by gallic acid derivatives. Biomed Res 23: 127-134, 2002.

6. Gardner PR: Aconitase: Sensitive target and measure of superoxide. Methods Enzymol 349: 9-23, 2002.

7. Gladysheva IP, Moroz NA, Karmakova TA, Nemtsova ER, Yakubovskaya RI and Larionova NI: Immunoconjugates of soybean Bowman-Birk protease inhibitor as targeted antitumor polymeric agents. J Drug Target 9: 303-316, 2001.
8. Marschütz MK and Bernkop-Schnürch A: Oral peptide drug delivery: Polymer-inhibitor conjugates protecting insulin from enzymatic degradation in vitro. Biomaterials 21: 1499-1507, 2000.

9. Malkowicz SB, Liu SP, Broderick GA, Wein AJ, Kennedy AR and Levin RM: Effect of the Bowman-Birk inhibitor (a soy protein) on in vitro bladder neck/urethral and penile corporal smooth muscle activity. Neurourol Urodyn 22: 54-57, 2003.

10. Supuran CT, Casini A and Scozzafava A: Protease inhibitors of the sulfonamide type: Anticancer, antiinflammatory, and antiviral agents. Med Res Rev 23: 535-558, 2003.

11. Birk Y: The Bowman-Birk inhibitor. Trypsin- and chymotrypsin-inhibitor from soybeans. Int J Pept Protein Res 25: 113-131, 1985.

12. Yavelow J, Finlay TH, Kennedy AR and Troll W: Bowman-Birk soybean protease inhibitor as an anticarcinogen. Cancer Res 43 (Suppl): 2454s-2459s, 1983.

13. Cryns V and Yuan J: Proteases to die for. Genes Dev 12: 1551-1570, 1998.

14. Hu W and Kavanagh JJ: Anticancer therapy targeting the apoptotic pathway. Lancet Oncol 4: 721-729, 2003.

15. Dias N and Bailly C: Drugs targeting mitochondrial functions to control tumor cell growth. Biochem Pharmacol 70: 1-12, 2005.

16. Schulze-Osthoff K, Ferrari D, Los M, Wesselborg S and Peter ME: Apoptosis signaling by death receptors. Eur J Biochem 254: 439-459, 1998.

17. Rao RV, Ellerby HM and Bredesen DE: Coupling endoplasmic reticulum stress to the cell death program. Cell Death Differ 11: 372-380, 2004

18. Budihardjo I, Oliver H,Lutter M, Luo X and Wang X: Biochemical pathways of caspase activation during apoptosis. Annu Rev Cell Dev Biol 15: 269-290, 1999.

19. Liu X, Kim CN, Yang J, Jemmerson R and Wang X: Induction of apoptotic program in cell-free extracts: Requirement for dATP and cytochrome $c$. Cell 86: 147-157, 1996.

20. Thorburn A: Death receptor-induced cell killing. Cell Signal 16: 139-144, 2004.

21. Lacour S, Micheau O, Hammann A, Drouineaud V, Tschopp J, Solary E and Dimanche-Boitrel MT: Chemotherapy enhances TNF-related apoptosis-inducing ligand DISC assembly in HT29 human colon cancer cells. Oncogene 22: 1807-1816, 2003.

22. Zhang Z, Li Y, Li C, Yuan J and Wang Z: Expression of a buckwheat trypsin inhibitor gene in Escherichia coli and its effect on multiple myeloma IM-9 cell proliferation. Acta Biochim Biophys Sin (Shanghai) 39: 701-707, 2007.

23. Wang ZH, Gao L, Li YY, Zhang Z, Yuan JM, Wang HW, Zhang L and Zhu L: Induction of apoptosis by buckwheat trypsin inhibitor in chronic myeloid leukemia K562 cells. Biol Pharm Bull 30: 783-786, 2007.

24. Park SS and Ohba H: Suppressive activity of protease inhibitors from buckwheat seeds against human T-acute lymphoblastic leukemia cell lines. Appl Biochem Biotechnol 117: 65-74, 2004.

25. Stennicke HR and Salvesen GS: Properties of the caspases. Biochim Biophys Acta 1387: 17-31, 1998.

26. Hengartner MO: The biochemistry of apoptosis. Nature 407: 770-776, 2000.

27. Park JW, Choi YJ, Suh SI, Baek WK, Suh MH, Jin IN, Min DS, Woo JH, Chang JS, Passaniti A, et al: Bcl-2 overexpression attenuates resveratrol-induced apoptosis in U937 cells by inhibition of caspase-3 activity. Carcinogenesis 22: 1633-1639, 2001.

28. Kaufmann SH and Hengartner MO: Programmed cell death: Alive and well in the new millennium. Trends Cell Biol 11: 526-534, 2001.

29. Li P, Nijhawan D, Budihardjo I, Srinivasula SM, Ahmad M, Alnemri ES and Wang X: Cytochrome $c$ and dATP-dependent formation of Apaf-1/caspase-9 complex initiates an apoptotic protease cascade. Cell 91: 479-489, 1997.

30. Narayanan S, Surolia A and Karande AA: Ribosome-inactivating protein and apoptosis: Abrin causes cell death via mitochondrial pathway in Jurkat cells. Biochem J 377: 233-240, 2004.

31. Smith EM and Jayson GC: The current and future management of malignant ascites. Clin Oncol (R Coll Radiol) 15: 59-72, 2003. 